\title{
Exercised-based methods to treat adult scoliosis: adult case report Marjorie T Nieh
}

\author{
Address: Rensselaer, NY 12144, USA \\ Email: Marjorie T Nieh - niehmar@yahoo.com
}

from 4th International Conference on Conservative Management of Spinal Deformities Boston, MA, USA. 13-16 May 2007

Published: 12 October 2007

Scoliosis 2007, 2(Suppl I):P8 doi:10.II86/I748-7|6I-2-SI-P8

This abstract is available from: http://www.scoliosisjournal.com/content/2/SI/P8

(c) 2007 Nieh; licensee BioMed Central Ltd.

\section{Objective}

Severe scoliosis (Cobb angle $>50$ degrees) in adult populations is associated with increased pain, reduced vital capacity, and mean progression of ten degrees per decade $[1,2]$. Few nonsurgical approaches to prevent progression and maintain health related quality of life (HRQL) have been documented [3].

\section{Study design}

This study is a self-described case report of a sixty fiveyear-old female with severe scoliosis (Cobb angle 60-65 degrees), who was diagnosed at age 28 years, and was not treated surgically. A multimodal approach using lowimpact and high-impact exercises offered through the YMCA, yoga and Tae Kwon Do Centers was used. These included aerobics, step aerobics, boot camps, pilates, yoga, nia, body conditioning, kickboxing and martial arts.

\section{Results}

Flexibility and mobility have been maintained, and subjectively the deformity is not obvious to observers. Back pain severity has been reduced, but a lumbar support belt is still needed to perform house chores such as vacuuming and gardening. Heavy lifting is avoided.

\section{Conclusion}

Self-chosen and non-prescribed exercises were used to maintain function in a patient at high risk for reduced HRQL.

\section{References}

I. Collis DK, Ponseti IV: Long-term follow-up of patients with IS scoliosis not treated surgically. J Bone Jt Surg 1969, 5IA:425-445.
2. Mayo NE, Goldberg MS, Poitras B, Scott S, Hanley J: The Ste-Justine AIS cohort study. Part III: Back pain. Spine I994, I4: I573-I58I. 3. Blum CL: Chiropractic and pilates therapy for the treatment of adult scoliosis. J Manip Physiol Therapeutics 2002, 25:E3. 